\title{
The demand for life insurance in a developing country and the mediating role of persuasion
}

\author{
Darian Low Eng Swee \\ Asia e University, \\ Malaysia \\ darianlow_mba@yahoo.com
}

Robert Jeyakumar Nathan

Multimedia University,

Malaysia

robert.jeyakumar@mmu.edu.my

\section{Eva Gorgenyi-Hegyes}

Hungarian University of Agriculture and Life Sciences,

Hungary

gorgenyieva@,gmail.com

\section{Maria Fekete-Farkas}

Hungarian University of Agriculture and Life Sciences,

Hungary

Farkasne.Fekete.Maria@uni-mate.bu

Abstract. This study examines the demand for life insurance in a rapidly developing economic environment in South East Asia, focusing on Malaysia. The study extends the Elaboration Likelihood Model (ELM) by introducing a mediating variable 'Persuasion' in examining the demand for life insurance among policy buyers. Fuelled by the recent COVID-19 pandemic, the life insurance market is expected to grow significantly and the role of the state and regulatory body to regulate this process would be pivotal. Given the increasing significance of this industry both before and after the epidemic, this study identifies seven research variables from previous literature sources related to finance and international insurance, including financial literacy, saving motives, religiosity, risk aversion, agent, persuasion and purchase intention of life insurance. A causal research design is used to formulate research framework and testable hypotheses for this study. Data collection encompasses face to face interviews with 385 life insurance policy holders between May 2019 and March 2020 by using a survey

Received:

March, 2021

1st Revision:

August, 2021

Accepted:

September, 2021

DOI:

$10.14254 / 2071$ 8330.2021/14-3/9 
questionnaire. Data analysis is mainly based on PLS-SEM method by using SPSS and Smart PLS statistical software packages. Results reveal persuasion as an important construct that explains the demand for life insurance, while agent is found to have the highest impact towards persuasion. The study also finds a full mediation effect of persuasion in the demand for life insurance for risk aversion and agent. These findings add new insights to the body of knowledge in life insurance literatures. Furthermore, research is useful for policy makers including government, finance, and insurance agencies; and recommends relevant strategies to further improve life insurance penetration in the population.

Keywords: life insurance, persuasion, financial literacy, religiosity, elaboration likelihood model, Malaysia.

JEL Classification: G22, D12

\section{INTRODUCTION}

Insurance sector has developed alongside with the other important financial sectors to overcome the uncertainties of the volatile economy (Diebold et al., 2015). The concept of insurance has been in existence since ancient times as insurance plays a vital role in the economy and society based on the premium it collects, the scale of its investments globally and regionally, and more importantly the essential role it plays in covering personal and business risks (OECD, 2021). Among the various insurance products, life insurance policies have become of special focus and interest due to the pandemic outbreak of COVID-19. The pandemic has both positive and negative impacts towards the world economy. Between March and June of 2020, a series of surveys conducted with the general public in the United Kingdom, the United States and Spain found that 30\% of respondents stated COVID-19 had made them more likely to consider obtaining life insurance (Descombes, 2021).

Swiss Re Institute (2021b) estimated that global insurance demand would increase at an above-trend rate of $3.3 \%$ in 2021 and $3.9 \%$ in 2022, a significantly quicker recovery than the global financial crisis (GFC) of 2008-09. Therefore, the epidemic has ushered in favourable insurance paradigm adjustments. One important demand driver is a considerable increase in risk awareness. Consumers felt they are under insured and demanded for more comprehensive life insurance coverage. Consumers in China, the first market to face the pandemic and recover from the health catastrophe, are more likely to buy new insurance once their lives return to normal in 2021 than they were a year ago (Swiss Re Institute, 2021b). According to surveys conducted by Swiss Re Institute (2021a) in Asia Pacific markets in 2021, during the pandemic, 30-40\% of respondents acquired supplementary life and health insurance and $25 \%$ to $50 \%$ of people still plan to get new insurance plans. Demand for online transaction of life insurance is also a growing trend. Consumers have swiftly acclimated to internet channels and are increasingly preferring to transact digitally at all points of contact with insurance companies.

This is especially important in developing economies where public healthcare systems lack the infrastructure to provide for free public healthcare services unlike in developed economies, which leads to more people purchasing personal life insurance protection policies in order to cover themselves and their family members in case of medical emergencies, to finance private hospital medical cost. This study explores the life insurance demand in a rapidly developing economy in Asia, Malaysia. Malaysia has been rapidly developing in consumerism and entrepreneurship activities, both in physical and in online economic 
frontiers, as well as emulating and growing with other larger economies in the region such as Singapore (Nathan et al., 2019; Tanti et al., 2021).

Based on the latest published data of year 2020, the Malaysian life insurance sector has recorded a positive sum assured in force, with growth of $4.3 \%$ in 2020 compared to the previous year; worth RM 1.7 trillion (approximately USD410 billion) in sum assured (LIAM, 2021). The sum assured per capita also increased from RM50,157 in 2019 to RM51,988 in 2020 (LIAM, 2021). Notwithstanding, the per capita sum assured of RM51,988 is still lacking in the event of unfortunate events to the insured. The ideal sum assured for each family member is about RM100,000 to RM150,000 as indicated by the 2012 Underinsurance Study in Malaysia, which is recommended by LIAM and Universiti Kebangsaan Malaysia in 2013 (Life Insurance Association of Malaysia, 2013). Currently, the sum assured per capita in Malaysia is still relatively low which translates into an underinsurance situation for life insurance in the country.

However, the overall life insurance density and penetration rate are generally lower in developing economies such as Malaysia compared to developed Asian nations. It is a race against time to increase this penetration rate especially during the threat of health pandemic. In the last decade, several researchers have sought to determine the factors influencing the demand for life insurance in Malaysia, particularly in the area of Takaful Insurance which mean Sharia compliant insurance products (Arifin, 2015; Arifin et al., 2013; Ismail et al., 2015; Mohamed \& Syed Othman Alhabshi, 2013; Nor \& Kamil, 2014; Redzuan, 2011, 2014; Remli et al., 2018; Yazid et al., 2012). However, persuasion which represents the mediating construct of the conceptual model has not been empirically tested in relation to the demand for life insurance. In addition, existing previous studies have not integrated the Elaboration Likelihood Model in investigating the mediating role of persuasion in demand for life insurance. Most studies in the area of persuasion and consumers in the region focuses on retail consumers in general (Victor et al., 2018; Ng et al, 2018; Nathan et al., 2021), without emphasis on the demand for life insurance among prospective insurance purchasers. Insurance policies offer intangible benefits at the point of sales, and require a certain level of motivation and ability to accept the intangible benefits. As such, insurance consumers are unique in their consumer response and behaviour where they need to be educated, counselled, motivated, and often persuaded to act.

This research aims to identify and measure crucial factors associated with the demand for life insurance in Malaysia, through an international literature review in the domains of insurance purchase behaviour. To systematically evaluate the demand for life insurance, a relevant theory Elaboration Likelihood Model is adopted in this study and further the theory extended by introducing a mediating variable 'persuasion' to improve its explanatory power to predict behaviour in the context of insurance purchase.

To this extent, the present research is structured in the following order. Section 2 presents the literature review where previous seminal works in insurance industry are systematically discussed with a special focus on the international importance of the topic. Section 3 describes the research methodology where the research framework and data collection procedures are discussed. It is followed by Section 4 which presents the empirical research findings and results of hypothesis testing. Finally, Section 5 concludes this study by highlighting its main contribution to the field of insurance industry and presents the agenda for further research. 


\section{LITERATURE REVIEW}

To evaluate the situation of Malaysian insurance industry, it is necessary to compare its performance (based on penetration and density) to other countries in the same region as well as to examine the insurance demand factors from international perspective based on existing literatures. According to studies conducted by Loke (2015) and Loke \& Goh (2013), insurance density is measured by the ratio of premium income to the total population (premium per capita) and insurance penetration rate as a \% of Gross Domestic Product (GDP) measures contributions of life insurance premium to the country's GDP in percentage terms. Life insurance density in Malaysia was at USD380 in 2019 compared to USD 8879 of Hong Kong which is the highest among the selected Asian countries. The neighbouring country, Singapore also recorded higher insurance density at USD3835 (Swiss Re Institute, 2021b).

Central Bank of Malaysia defines market penetration as the ratio of the number of policies in force as a proportion to the total population. As of 2018, the penetration rate was at 54\% (Bernama.com, 2019). In addition, life insurance penetration rate in Malaysia (as a \% of GDP) is only at 3.35\% whereas in the neighbouring country Singapore it is 5.96\%. Taiwan recorded the highest penetration rate among the Asian countries with 16.51\% (Swiss Re Institute, 2021b). Taiwan is a mature market whereby the value of the life insurance is well understood by most citizens. Reinsurers have a very strong acceptance as Taiwan has an ageing population, making life insurance is a priority to the country. Public and workplace pensions are insufficient, and people need to save for themselves to generate a flow of income and this increases the demand for savings and annuity products. Additionally, the bank deposit interest rate is very low in Taiwan that people are prepared to shift their savings into higher return instruments. Moreover, banks intend to sell insurance as an additional product to gain profits from insurance sales commissions. The banking channel has expanded considerably over the years as the demand for the life insurance products increases. Singapore's excellent performance in the field of life insurance and penetration rate in Asia's neighbouring country indicates that there is a growing consciousness among people about the value of life insurance in developed Asian economies compared to the developing economies.

As social protection of population is closely related to economy and its determinants, researchers analysed its system as a mechanism to stimulate the economic development (Malyovanyi et al., 2018). According to Arych and Darcy (2020) the life insurance industry is one of the most important and powerful tools for social and economic welfare. The insurance demand has been examined empirically for more than 50 years internationally (Liebertberg et al., 2012). As many researchers emphasize, insurance industry has been historically influenced by numerous internal and external factors. After reviewing the literature pertaining to factor influencing the demand for life insurance in Malaysia and the mediating role of persuasion together with several gaps were identified. With the exception of Mahdzan and Victorian (2013) and Zakaria et al. (2016), majority of the studies focused on the socio-demographic and socio-economic aspects of the demand for life insurance (Schlag, 2003; Dragos et al., 2017). For example, Dash (2018) performed his study in India, and found that the life insurance demand is positively affected by the level of education and occupation, however, the premiums cost of life insurance negatively influences its demand. Sliwinski et al. (2013) analysed the Polish life insurance market in their study and concluded that the factor of an economic and financial nature (with such merging variables as GDP, inflation, dependency rate, birth rate etc.) strongly stimulates the demand for life insurance which is very similar in western countries too. Socio-economic variables affect the demand also in Central and Southeastern Europe (Kjosevski, 2012).

Similarly, Mapharing et al. (2015) conducted a study in Canada based on economic variables (such as life insurance density, income, inflation, education, life expectancy, dependency rate etc.) and suggested also identifying country-specific determinants of life insurance. Buric et al. (2017) stated based on their results that demand for life insurance in Montenegro is highly influenced by age structure and education as 
demographic factors as well as level of employment as economic factor. Nevertheless, there are some important differences between emerging economies from Asia and Europe - for example, Dragos (2014) found that urbanization significantly influences the life insurance demand in Asia, but not in Europe.

Structural Equation Modelling (SEM) statistical method is suitable for structural model and data analysis in the financial area (Brychko et al., 2020) and regularly used in research related to life insurance sector, for example in study of Hao et al. (2017) conducted among life insurance agents in Tianjin, China.. Based on international literatures on life insurance, 6 crucial variables namely financial literacy, saving motives, religiosity, risk aversion, agent and persuasion were identified to form the framework for this research.

Financial literacy is a much-researched area not only from the side of individuals, but also from corporate point of view in the financial sector (Toth et al., 2021). Financial literacy is among the most important variables in influencing the demand for life insurance (Mahdzan \& Tabiani, 2013; Shafii et al., 2009). A positive relationship is expected between individuals' financial literacy and the demand for life insurance based on the literature review. Four aspects of saving motives have been built up for the purpose of this study which is firmly related to the demand of life insurance. This study is in line with previous studies undertaken by Mahdzan and Tabiani (2013) and Zakaria et al. (2016) which include the similar aspects of saving motives. Md Masnun Al Mahi et al. (2017) believes that religiosity determinants have gained popularity in the business research especially with regards to the individual's decision making. Considering this, we identify religious convictions of a consumer as a pertinent factor in their consideration for a life insurance policy. Loke and Goh (2013) argued that the interest for extra security possibly impact the hazard inclination of a person as the items empowers people to exchange their hazard to the insurance agencies in vulnerable conditions. As such, risk averse individuals are bound to purchase life insurance to protect themselves against hazard (Friedman \& Savaje, 1948). Insurance is one of the most important tools to manage risk and operates on the principles of risk pooling (Lorant \& Fekete-Farkas, 2015). The role of the insurance agents in the Malaysia's scene is fundamental in assuring the products are generally accessible, by improving the positive effect of the market infiltration. In todays' world, intermediary is not limited with consumers and agent interactions but also the role of internet technology such as websites and social networks. Based on the literature review, the role of the insurance agents in the Malaysia's landscape is essential in assuring the products are widely available, thereby enhance the positive impact of the market penetration. Persuasion represents the mediating construct in the conceptual model. Most studies in the area of persuasion focused on consumerism in general, however, it has not been empirically tested in relation to the demand for life insurance. Insurance policies offer intangible benefits at the point of sales and require a certain level of motivation and ability to accept the intangible benefits. As such, consumers need to be educated, convinced, counselled, motivated and persuaded to take action. Prospective insurance policy purchasers would procrastinate their decision to buy life insurance without the intervention of the life insurance agent (Onifade, 2011). Salleh and Kamaruddin (2011) in their study found that insurance agent with high level of persuasion and negotiation will perform well in the life insurance industry.

Based on the discussions above, the following hypotheses are forwarded for testing:

H1: Demand for Life Insurance is significantly influenced by Financial Literacy.

H2: Saving Motives have a positive impact on the Demand for Life Insurance.

H3: There is a positive impact of Religiosity towards Demand for Life Insurance.

H4: There is a positive impact of Risk Aversion towards Demand for Life Insurance.

H5: Agent directly influences the Demand for Life Insurance.

H6: Persuasion has a positive impact on the Demand for Life Insurance.

H7: Persuasion significantly mediates the relationships between the Demand for Life Insurance and all the following variables: Financial Literacy, Saving Motives, Religiosity, Risk Aversion and Agent. 


\section{RESEARCH METHODOLOGY}

Elaboration Likelihood Model (ELM) explains how attitudes are formed and reinforced by the persuasive arguments (Petty and Cacioppo, 1986; Petty and Cacioppo, 1984). Individual will process the persuasive information presented with a certain level of elaboration (high or low) depending on his/her motivation on the information and ability to process the information. The thinking process will be more thorough and systematic if the information communicated captured the interest of the individuals. Vice versa, to those who did not view the messages as important to them (Cyr et al., 2018). Elaboration Likelihood Model generated a wealth of research knowledge in consumer psychology and became the most popular in consumer research (Lien, 2001) after its introduction in 1981 (Petty and Cacioppo, 1986). This research utilized ELM to affirm the impact of persuasion in mediating the relationship of the hypothesize factors on the demand for life insurance.

In this quantitative research, data was collected through a face-to-face survey using a structured questionnaire. The main reasons of use personal questionnaire survey as the main method for data collection were the sensitivity of the financial information and personal data required for this study. In accordance to Personal Data Protection Act 2010 (PDPA), financial institutions such as insurance companies are responsible to protect consumers' personal data from unauthorized use, modification, alteration and accidental access. The questionnaire was adopted and adapted based on the instrument found in the existing literatures. Constructs were operationalised by using 5 points Likert scales.

Section A of the questionnaire comprised of the following 8 questions in order to identify the demographic and socio-economic characteristics of the respondents: gender, age, marital status, number of households, ethnicity, religion, highest education achievement and monthly income. Other than age, the questions were presented in categorical format. Adapted from Lusardi (2015), Section B of the questionnaire solicited respondents their apparent dimension of financial literacy knowledge. The questions involved the basic and advanced level of financial literacy of the respondents. Section $\mathrm{C}$ of the questionnaire measured respondents' saving motives. The instrument was adapted from Mahdzan \& Peter Victorian (2013). Section $\mathrm{D}$ of the questionnaire measured respondent's religiosity. The instrument was adapted from Worthington et al. (2003) Religious Commitment Inventory-10 (RCI-10). Jamaludin (2012), Aliman, Ariffin, \& Hashim (2018) and Shahab et al. (2019) were the most recent authors adapted the Religious Commitment Inventory - 10 (RCI-10) in their studies in the Malaysia financial context. Risk aversion instrument in section $\mathrm{E}$ was adapted from financial risk tolerance questionnaire of Jacobs-Lawson \& Hershey (2005). Section F of the questionnaire measured respondent's evaluation on the sales agent which effected their insurance purchasing behavior were also based on previous literatures (Bieck et al., 2012; Chimedtseren \& Safari, 2016; Hasyim, 2017; Mahdzan et al., 2013; Panigrahi et al., 2018; Yu \& Tseng, 2016). Five items were identified to measure the persuasion construct in section $G$ based on the literature review which is trustworthy, emotion, clarity, persistent and overall persuasion (Bieck et al., 2012; Boubehrezh \& Iraji, 2013; Gadzhiyeva \& Sager, 2017).

The target population of this study are the life insurance policyholders residing in Malaysia. The sampling locations are from the 3 major cities in Malaysia: Selangor, Johor and Penang states. According to the Malaysian Takaful Association (MTA) report (2013), those living in these 3 major cities (Selangor, Johor and Penang) has the largest protection gap in Malaysia due to the higher number of working populations working in this area (Malaysian Takaful Association, 2013).

Life insurance policyholders age 18 and selected as the sampling unit for this study as it is believed that this group of respondents are independent and able to make their own decision in purchasing the life insurance products. This is supported by the Law of Malaysia under the Age of Majority Act 1971 which 
state individuals at the age of 18 has legal control over their decisions and actions (Attorney General's Chamber of Malaysia, 2006).

Judgmental and purposive sampling technique were used for this study as the respondents of age 18 and above will be ideal to provide the best information to achieve the objective of this study. A sample size of 384 were gathered in data collection stage based on Krejcie and Morgan (1970) calculations at significance level $\mathrm{P}<.05$. The questionnaire was administrated in a public place such as shopping malls, and walkways outside banks in the major cities, between May 2019 and March 2020. While approaching potential respondents, the objective of the study was explained to them and they were invited to participate in the questionnaire voluntarily. In order to randomize the selection of participants, at shopping mall entrance, researchers approached every fifth potential respondent who walked into the mall through the main entrance.

Statistical Package for Social Sciences (SPSS) version 21 was used to perform descriptive analysis of the research data while Smart PLS software version 2.0 was used to perform path modelling and to test the research hypotheses. The data analyses into two main sections as the followings: descriptive statistics and inferential statistics. Descriptive statistics discusses the socio-demographic characteristics of the respondents followed by normality and reliability analyses. The subsequent section analyses the inferential statistics which can be seen at the measurement model and structural model. The measurement model discusses the internal consistency reliability (composite reliability and Cronbach's alpha), convergent validity (outer loadings and average variance extracted) and discriminant validity (cross loading and Fornell-LarckerCriterion). Thereafter, this study analyses the structural model which include the collinearity assessment, coefficient of determination ( $\mathrm{R}^{2}$ values), effect size $f^{2}$, significance and relevance assessment and predictive relevance $\mathrm{Q}^{2}$. The final section discusses the mediating role of persuasion between risk aversion and sales agent with the demand for life insurance.

\section{RESULTS AND DISCUSSION}

\subsection{Descriptive statistics}

Upon the completion of data collection, 384 responses were finalized for data analysis. Both genders are almost equally represented in this study with $45.5 \%$ of the respondents coming from male and $54.5 \%$ of the respondents coming from female. $43.9 \%$ respondents from the age group of 23-37 formed the data of this study which is a normal distribution given the entry age for young adults to the working world in Malaysia is around the age of 23. This is the time when young adults start to earn for living and start to purchase life insurance products. Majority of the respondents participated in this study are married which consists of the $67.8 \%$ of the total sample. Majority of the respondents come from a family of $1-3$ which consists $60.8 \%$ of the total respondents. Majority of the respondents are Malay (50.6\%) which corresponds with the national statistics of Malaysians according to ethnicity. Detailed demographic data can be seen in Table 1. 
Respondents' demographics information

\begin{tabular}{|l|c|c|c|}
\hline Demographics & & Frequency & Percentage \\
\hline Gender & Male & 175 & 45.5 \\
& Female & 210 & 54.5 \\
\hline Age & 18 to 22 & 29 & 7.5 \\
& 23 to 27 & 59 & 15.3 \\
& 28 to 32 & 58 & 13.5 \\
& 33 to 37 & 52 & 10.6 \\
& 38 to 42 & 41 & 11.9 \\
& 43 to 47 & 46 & 7.5 \\
& 48 to 52 & 29 & 7.3 \\
& 53 to 57 & 28 & 7.3 \\
& 58 to 62 & 28 & 3.9 \\
\hline Relationship Status & 62 or older & 15 & 31.2 \\
& Single & 120 & 67.8 \\
& Married & 261 & 1.0 \\
\hline Number of Family & Others & 4 & 60.8 \\
& 1 to 3 & 234 & 35.6 \\
& 4 to 6 & 137 & 3.6 \\
\hline Ethnicity & Others & 14 & 50.6 \\
& Malay & 195 & 34.5 \\
& Chinese & 133 & 12.7 \\
\hline
\end{tabular}

Source: Authors' own evaluation.

\subsection{Normality and reliability analysis}

Two measures of distributions which are Skewness and Kurtosis used for this study. According to Chua (2013), values for skewness and kurtosis should be in the range of -1.96 to +1.96 for a data to be normally distributed. It appears in Table 2 that all the variables distribution scores are within the range of 1.96 to +1.96 , hence all the data are normally distributed.

Cronbach's alpha as a reliability method is commonly used to measure the internal consistency of a multiple item scale. According to Chua (2013), the alpha value of .65 to .95 is satisfactory. Table 2 shows the overall alpha value is between .65 to .95 , hence it indicates good reliability.

Table 2

Normality and Reliability Analysis

\begin{tabular}{|l|c|c|c|c|}
\hline “Variable & $\begin{array}{c}\text { Number of } \\
\text { Items }\end{array}$ & Skewness & Kurtosis & $\begin{array}{c}\text { Cronbach's } \\
\text { Alpha }\end{array}$ \\
\hline Financial Literacy & 5 & -.285 & -.158 & .907 \\
\hline Saving Motives & 4 & -.631 & .771 & .821 \\
\hline Religiosity & 5 & -.071 & -.203 & .879 \\
\hline Risk Aversion & 5 & -.665 & .857 & .831 \\
\hline Agent & 5 & -.361 & .454 & .865 \\
\hline Persuasion & 5 & -.628 & .387 & .892 \\
\hline Demand for Life Insurance" & 5 & -.542 & .800 & .891 \\
\hline
\end{tabular}

Source: Authors' own evaluation. 


\subsection{Evaluation of measurement models}

Internal consistency reliability: Traditionally, Cronbach's alpha was used as a measurement of the internal consistency of data. However, the measurement has an imperfection. Hair et al. (2017) suggested to apply composite reliability as a more reliable measurement tool. This is supported by McNeish (2017) who investigated alternative to measure reliability which is composite reliability. Hence, Authors used composite reliability as a measurement for reliability. The minimum threshold level for composite reliability is 0.70 (Hair et al., 2017). All composite reliability of this study exceed the threshold level with values of 0.903 (Agent), 0.920 (Demand for Life Insurance), 0.930 (Financial Literacy), 0.922 (Persuasion), 0.912 (Religiosity), 0.884 (Risk Aversion) and 0,881 (Saving Motives). Hence, all seven reflective constructs have high levels of internal consistency reliability.

Convergent validity: Based on the outer loadings of the reflective construct agent, demand for life insurance, financial literacy and persuasion are well above the threshold value of 0.708 which suggests sufficient levels of indicator reliability (Hair et al., 2017). The outer loading for religiosity 5 (R5), risk aversion 5 (RA5) and saving motives 1 (SM1) contributing to the AVE scores of the respective construct is above 0.6. Byrne (2012) has the opinion that the loading values equal to and greater than 0.6 are still acceptable if the average variance extracted (AVE) scores is greater than 0.6. Hence, all the reflective construct in this study have sufficient level of indicator reliability. According to Hair et al. (2017), convergent validity established when the Average Variance Extracted (AVE) value is 0.50 or higher. Hence, the measure of the seven reflective constructs (independent and dependent variables) have high levels of convergent validity.

Discriminant validity: The outer loading of the indicator assigned on the construct or latent variable should be greater than any of its cross loading on other construct or latent variable (Hair et al., 2017; Ramayah et al., 2018). Table 3 shows that discriminant validity is established as all the indicators' outer loading exceed the cross loading.

Table 3

Cross-Loadings analysis

\begin{tabular}{|l|c|c|c|c|c|c|c|}
\hline & Agent & $\begin{array}{c}\text { Demand } \\
\text { for Life } \\
\text { Insurance }\end{array}$ & $\begin{array}{c}\text { Financial } \\
\text { Literacy }\end{array}$ & Persuasion & Religiosity & $\begin{array}{c}\text { Risk } \\
\text { Aversion }\end{array}$ & $\begin{array}{c}\text { Saving } \\
\text { Motives }\end{array}$ \\
\hline A1 & $\mathbf{0 . 7 6 6}$ & 0.378 & 0.155 & 0.460 & 0.191 & 0.232 & 0.284 \\
\hline A2 & $\mathbf{0 . 8 5 1}$ & 0.507 & 0.098 & 0.614 & 0.210 & 0.274 & 0.305 \\
\hline A3 & $\mathbf{0 . 8 7 4}$ & 0.473 & 0.135 & 0.587 & 0.222 & 0.300 & 0.302 \\
\hline A4 & $\mathbf{0 . 7 6 2}$ & 0.432 & 0.234 & 0.442 & 0.210 & 0.277 & 0.336 \\
\hline A5 & $\mathbf{0 . 7 7 2}$ & 0.385 & 0.164 & 0.428 & 0.222 & 0.261 & 0.312 \\
\hline D1 & 0.439 & $\mathbf{0 . 8 3 4}$ & 0.139 & 0.619 & 0.255 & 0.301 & 0.365 \\
\hline D2 & 0.426 & $\mathbf{0 . 8 5 6}$ & 0.164 & 0.590 & 0.324 & 0.344 & 0.463 \\
\hline D3 & 0.420 & $\mathbf{0 . 8 1 5}$ & 0.075 & 0.579 & 0.286 & 0.336 & 0.336 \\
\hline D4 & 0.506 & $\mathbf{0 . 8 2 5}$ & 0.113 & 0.563 & 0.238 & 0.333 & 0.372 \\
\hline D5 & 0.481 & $\mathbf{0 . 8 4 3}$ & 0.116 & 0.560 & 0.271 & 0.376 & 0.423 \\
\hline FL1 & 0.164 & 0.130 & $\mathbf{0 . 8 5 0}$ & 0.013 & 0.325 & 0.187 & 0.432 \\
\hline FL2 & 0.177 & 0.141 & $\mathbf{0 . 8 5 6}$ & 0.056 & 0.342 & 0.147 & 0.388 \\
\hline FL3 & 0.139 & 0.134 & $\mathbf{0 . 8 9 8}$ & 0.079 & 0.204 & 0.193 & 0.408 \\
\hline FL4 & 0.157 & 0.130 & $\mathbf{0 . 8 7 9}$ & 0.110 & 0.163 & 0.192 & 0.367 \\
\hline FL5 & 0.169 & 0.091 & $\mathbf{0 . 7 7 8}$ & 0.150 & 0.143 & 0.217 & 0.353 \\
\hline P1 & 0.583 & 0.570 & 0.139 & $\mathbf{0 . 8 3 6}$ & 0.210 & 0.349 & 0.277 \\
\hline P2 & 0.460 & 0.566 & 0.096 & $\mathbf{0 . 7 7 9}$ & 0.205 & 0.244 & 0.280 \\
\hline P3 & 0.565 & 0.611 & 0.065 & $\mathbf{0 . 8 6 5}$ & 0.230 & 0.322 & 0.290 \\
\hline P4 & 0.546 & 0.609 & 0.020 & $\mathbf{0 . 8 7 3}$ & 0.202 & 0.312 & 0.264 \\
\hline P5 & 0.506 & 0.566 & 0.111 & $\mathbf{0 . 8 3 4}$ & 0.143 & 0.323 & 0.233 \\
\hline R1 & 0.281 & 0.288 & 0.260 & 0.207 & $\mathbf{0 . 8 0 8}$ & 0.365 & 0.367 \\
\hline R2 & 0.239 & 0.314 & 0.256 & 0.206 & $\mathbf{0 . 8 7 0}$ & 0.344 & 0.356 \\
\hline
\end{tabular}




\begin{tabular}{|l|l|l|l|l|l|l|l|}
\hline R3 & 0.190 & 0.294 & 0.230 & 0.186 & $\mathbf{0 . 8 7 5}$ & 0.386 & 0.304 \\
\hline R4 & 0.222 & 0.254 & 0.151 & 0.207 & $\mathbf{0 . 8 4 8}$ & 0.311 & 0.336 \\
\hline R5 & 0.114 & 0.187 & 0.192 & 0.166 & $\mathbf{0 . 6 9 9}$ & 0.364 & 0.316 \\
\hline RA1 & 0.277 & 0.242 & 0.191 & 0.300 & 0.333 & $\mathbf{0 . 7 3 3}$ & 0.257 \\
\hline RA2 & 0.261 & 0.245 & 0.212 & 0.294 & 0.296 & $\mathbf{0 . 8 3 3}$ & 0.318 \\
\hline RA3 & 0.249 & 0.321 & 0.159 & 0.280 & 0.362 & $\mathbf{0 . 8 5 4}$ & 0.363 \\
\hline RA4 & 0.226 & 0.288 & 0.267 & 0.270 & 0.345 & $\mathbf{0 . 7 7 8}$ & 0.401 \\
\hline RA5 & 0.272 & 0.428 & 0.058 & 0.289 & 0.314 & $\mathbf{0 . 6 8 3}$ & 0.338 \\
\hline SM1 & 0.231 & 0.194 & 0.327 & 0.183 & 0.107 & 0.195 & $\mathbf{0 . 6 2 6}$ \\
\hline SM2 & 0.313 & 0.369 & 0.399 & 0.253 & 0.355 & 0.378 & $\mathbf{0 . 8 4 2}$ \\
\hline SM3 & 0.334 & 0.457 & 0.340 & 0.303 & 0.374 & 0.405 & $\mathbf{0 . 8 7 4}$ \\
\hline SM4 & 0.334 & 0.433 & 0.415 & 0.277 & 0.400 & 0.382 & $\mathbf{0 . 8 6 6}$ \\
\hline
\end{tabular}

Source: Authors' own evaluation.

Table 4 shows that the square roots of the AVE for the reflective construct Agent (0.806), demand for life insurance $(0.835)$, financial literacy $(0.853)$, persuasion $(0.838)$, religiosity $(0.823)$, risk aversion $(0.779)$ and saving motives (0.808) are all higher than correlations of this constructs with other latent variable in the path model, hence indicating that all the above mentioned constructs are measuring the unique concept.

Table 4

Fornell-Larcker criterion analysis

\begin{tabular}{|l|c|c|c|c|c|c|c|}
\hline & Agent & $\begin{array}{c}\text { Demand } \\
\text { for Life } \\
\text { Insuranc } \\
\mathbf{e}\end{array}$ & $\begin{array}{c}\text { Financial } \\
\text { Literacy }\end{array}$ & $\begin{array}{c}\text { Persuasio } \\
\mathbf{n}\end{array}$ & $\begin{array}{c}\text { Religiosit } \\
\mathbf{y}\end{array}$ & $\begin{array}{c}\text { Risk } \\
\text { Aversion }\end{array}$ & $\begin{array}{c}\text { Saving } \\
\text { Motives }\end{array}$ \\
\hline Agent & $\mathbf{0 . 8 0 6}$ & & & & & & \\
\hline $\begin{array}{l}\text { Demand for Life } \\
\text { Insurance }\end{array}$ & 0.544 & $\mathbf{0 . 8 3 5}$ & & & & & \\
\hline Financial Literacy & 0.189 & 0.146 & $\mathbf{0 . 8 5 3}$ & & & & \\
\hline Persuasion & 0.637 & 0.698 & 0.102 & $\mathbf{0 . 8 3 8}$ & & & \\
\hline Religiosity & 0.261 & 0.330 & 0.267 & 0.237 & $\mathbf{0 . 8 2 3}$ & & \\
\hline Risk Aversion & 0.334 & 0.405 & 0.220 & 0.371 & 0.427 & $\mathbf{0 . 7 7 9}$ & \\
\hline Saving Motives & 0.379 & 0.470 & 0.453 & 0.321 & 0.408 & 0.436 & $\mathbf{0 . 8 0 8}$ \\
\hline
\end{tabular}

Source: Authors' own evaluation.

\subsection{Evaluation of the structural model}

Collinearity assessment results present that all the VIF values are below the threshold of 5 . Therefore, based on Hair et al. (2017) collinearity among the predictor are not a critical issue.

Examining the Coefficient of Determination ( $\mathrm{R}^{2}$ Values) it can be clearly seen that - according to Hair et al. (2017) and Henseler et al. (2009) based on the values guideline of $0.50-\mathrm{R}^{2}$ values of demand for life insurance and persuasion can be considered moderate which is indicated in Table 5.

Table 5

$\mathrm{R}^{2}$ Values

\begin{tabular}{|l|c|c|}
\hline & R Square & R Square Adjusted \\
\hline Demand for Life Insurance & 0.571 & 0.564 \\
\hline Persuasion & 0.439 & 0.431 \\
\hline
\end{tabular}

Source: Authors' own evaluation.

Table 6 shows the Effect Size $\mathrm{f}^{2}$ results. Agent has no effect on demand for life insurance (0.010) but large effect on persuasion (0.471). Financial literacy has no effect on demand for life insurance (0.008) or 
persuasion (0.007). Persuasion has large effect on demand for life insurance (0.371). Religiosity has no effect on demand for life insurance (0.010) or persuasion (0.000). Risk aversion has no effect on demand for life insurance $(0.005)$ but small effect on persuasion $(0.035)$. Saving motives have small effect on demand for life insurance (0.082) but no effect on persuasion (0.004).

Table 6

$\mathrm{f}^{2}$ Effect Sizes

\begin{tabular}{|l|c|c|c|c|c|c|c|}
\hline & Agent & $\begin{array}{c}\text { Demand } \\
\text { for Life } \\
\text { Insurance }\end{array}$ & $\begin{array}{c}\text { Financial } \\
\text { Literacy }\end{array}$ & $\begin{array}{c}\text { Persuasio } \\
\mathbf{n}\end{array}$ & $\begin{array}{c}\text { Religiosit } \\
\mathbf{y}\end{array}$ & $\begin{array}{c}\text { Risk } \\
\text { Aversion }\end{array}$ & $\begin{array}{c}\text { Saving } \\
\text { Motives }\end{array}$ \\
\hline Agent & & 0.010 & & 0.471 & & & \\
\hline $\begin{array}{l}\text { Financial } \\
\text { Literacy }\end{array}$ & & 0.008 & & 0.007 & & & \\
\hline Persuasion & & 0.371 & & & & & \\
\hline Religiosity & & 0.010 & & 0.000 & & & \\
\hline $\begin{array}{l}\text { Risk } \\
\text { Aversion }\end{array}$ & & 0.005 & & 0.035 & & & \\
\hline $\begin{array}{l}\text { Saving } \\
\text { Motives }\end{array}$ & & 0.082 & & 0.004 & & & \\
\hline
\end{tabular}

Source: Authors' own evaluation.

As significance and relevance assessment we can state with regards to the demand for life insurance that persuasion has the strongest total effect among the five exogenous drivers construct on the demand for life insurance, followed by agent (0.391), saving motives (0.274), risk aversion (0.143), religiosity (0.083) and financial literacy (-0.105). The details are presented in Table 7.

Table 7

Total effects

\begin{tabular}{|l|l|c|l|c|c|c|c|}
\hline & Agent & $\begin{array}{c}\text { Demand } \\
\text { for Life } \\
\text { Insuranc } \\
\mathbf{e}\end{array}$ & $\begin{array}{c}\text { Financial } \\
\text { Literacy }\end{array}$ & $\begin{array}{c}\text { Persuasio } \\
\mathbf{n}\end{array}$ & $\begin{array}{c}\text { Religiosit } \\
\mathbf{y}\end{array}$ & $\begin{array}{c}\text { Risk } \\
\text { Aversion }\end{array}$ & $\begin{array}{c}\text { Saving } \\
\text { Motives }\end{array}$ \\
\hline Agent & & 0.391 & & 0.569 & & & \\
\hline $\begin{array}{l}\text { Demand for Life } \\
\text { Insurance }\end{array}$ & & & & & & & \\
\hline Financial Literacy & & -0.105 & & -0.073 & & & \\
\hline Persuasion & & 0.533 & & & & & \\
\hline Religiosity & & 0.083 & & 0.013 & & & \\
\hline Risk Aversion & & 0.143 & & 0.165 & & & \\
\hline Saving Motives & & 0.274 & & 0.061 & & & \\
\hline
\end{tabular}

Source: Authors' own evaluation.

The six hypotheses seek to establish direct paths between the independent variable, mediating variable and dependent variable; whereby for $\mathrm{H} 1$ the path of Financial Literacy to Demand for Life Insurance (Financial Literacy -> Demand for Life Insurance); H2 the path of Saving Motives to Demand for Life Insurance (Saving Motives -> Demand for Life Insurance); H3 the path of Religiosity to Demand for Life Insurance (Religiosity -> Demand for Life Insurance); H4 the path of Risk Aversion to Demand for Life Insurance (Risk Aversion -> Demand for Life Insurance); H5 the path of Agent to Demand for Life Insurance (Agent -> Demand for Life Insurance); and H6 the path of Persuasion to Demand for Life Insurance (Persuasion -> demand for Life Insurance). Table 8 shows the result summary. 
Table 8

Significance testing results

\begin{tabular}{|l|l|c|c|c|c|}
\hline H\# & Path & $\begin{array}{c}\text { Path } \\
\text { Coefficient }\end{array}$ & t Values & p Values & Significance \\
\hline H1 & $\begin{array}{l}\text { Financial Literacy -> Demand for Life } \\
\text { Insurance }\end{array}$ & -0.066 & 1.376 & 0.169 & No \\
\hline H2 & Saving Motives -> Demand for Life Insurance & 0.241 & 5.408 & $0.000^{* *}$ & Yes \\
\hline H3 & Religiosity -> Demand for Life Insurance & 0.077 & 1.866 & $0.062^{*}$ & Yes \\
\hline H4 & Risk Aversion -> Demand for Life Insurance & 0.055 & 1.395 & 0.163 & No \\
\hline H5 & Agent -> Demand for Life Insurance & 0.088 & 1.629 & 0.103 & No \\
\hline H6 & Persuasion -> Demand for Life Insurance & 0.533 & 10.320 & $0.000^{* *}$ & Yes \\
\hline H7a & Financial Literacy -> Persuasion & -0.073 & 1.298 & 0.194 & No \\
\hline $\begin{array}{l}\text { H7 } \\
\text { b }\end{array}$ & Saving Motives -> Persuasion & 0.061 & 1.167 & 0.243 & No \\
\hline H7c & Religiosity -> Persuasion & 0.013 & 0.268 & 0.789 & No \\
\hline $\begin{array}{l}\text { H7 } \\
\text { d }\end{array}$ & Risk Aversion -> Persuasion & 0.165 & 3.243 & $0.001 * *$ & Yes \\
\hline H7e & Agent -> Persuasion & 0.569 & 12.900 & $0.000^{* *}$ & Yes \\
\hline Sour A & & & & Non \\
\hline
\end{tabular}

Source: Authors' own evaluation.

The predictive relevance of the path model was assessed using the blindfolding procedure. Table 9 shows the blindfolding results which focus on the Construct Cross validated Redundancy. Q ${ }^{2}$ values of both endogenous constructs are considerably above 0 . More precisely, demand for life insurance has higher $\mathrm{Q}^{2}$ values $(0.375)$, followed by persuasion (0.290). This result indicates the acceptable predictive relevance of the model.

Table 9

Construct cross-validated redundancy ( $\mathrm{Q}^{2}$ Values $)$

\begin{tabular}{|l|c|c|c|}
\hline & SSO & SSE & $\mathbf{Q}^{2}$ (=1-SSE/SSO) \\
\hline Agent & $1,925.000$ & $1,925.000$ & \\
\hline Demand for Life Insurance & $1,925.000$ & $1,203.777$ & 0.375 \\
\hline Financial Literacy & $1,925.000$ & $1,925.000$ & 0.290 \\
\hline Persuasion & $1,925.000$ & $1,366.175$ & \\
\hline Religiosity & $1,925.000$ & $1,925.000$ & \\
\hline Risk Aversion & $1,925.000$ & $1,925.000$ & \\
\hline Saving Motives & $1,540.000$ & $1,540.000$ & \\
\hline
\end{tabular}

Source: Authors' own evaluation.

\subsection{Mediation analysis}

Based on the preceding analysis, it is expected that persuasion mediates the relationship between risk aversion and demand for life insurance as well as agent and demand for life insurance. The findings in Table 10 provides empirical support for the mediating role of persuasion in the structural model. More specifically, persuasion represents a mechanism that underlies the relationship between risk aversion and demand for life insurance as well as agent and demand for life insurance. Risk aversion leads to persuasion and 
persuasion in turn leads to demand for life insurance. Similarly, agent leads to persuasion and persuasion in turn leads to demand for life insurance. The study concludes that there is a presence of a full mediation effect of persuasion in this study with regards to risk aversion and agent.

Table 10

Significance analysis of the direct and indirect effects

\begin{tabular}{|l|c|c|c|c|c|c|c|c|}
\hline & $\begin{array}{c}\text { Direct } \\
\text { Effect }\end{array}$ & $\mathbf{t}$ Value & $\mathbf{p}$ Value & $\begin{array}{c}\text { Significa } \\
\text { nce } \\
(\mathbf{p}<\mathbf{0 . 0 5})\end{array}$ & $\begin{array}{c}\text { Indirect } \\
\text { Effect }\end{array}$ & $\mathbf{t}$ Value & $\mathbf{p}$ Value & $\begin{array}{c}\text { Significa } \\
\text { nce } \\
\mathbf{( p < 0 . 0 5 )}\end{array}$ \\
\hline $\begin{array}{l}\text { Risk Aversion } \\
\text { mDemand for Life } \\
\text { Insurance }\end{array}$ & 0.055 & 1.395 & 0.163 & No & 0.088 & 3.215 & 0.001 & Yes \\
\hline $\begin{array}{l}\text { Agent } \rightarrow \text { Demand for } \\
\text { Life Insurance }\end{array}$ & 0.088 & 1.629 & 0.103 & No & 0.303 & 7.325 & 0.000 & Yes \\
\hline
\end{tabular}

Source: Authors' own evaluation.

\section{CONCLUSION}

This study collectively analysed the effects of financial literacy, saving motives, religiosity, risk aversion, agent and persuasion towards the demand for life insurance which was sparse in the previous literatures. Studies on impact of persuasion with the application of the Elaboration Likelihood Model has not been empirically tested in a relation to the demand for life insurance, especially in a developing nation such as Malaysia. Findings supported presence of a full mediation effect of persuasion in this study with regards to risk aversion and agent which supports to extent the ELM model by linking persuasion as a mediating variable in the demand for life insurance.

Financial literacy is found to be insignificant for both direct and indirect relationships. It is also noted that saving motives and religiosity have a significant relationship with demand for life insurance. Risk aversion and agent do not have direct significant impact to the demand for life insurance but mediated by persuasion in the relationship with the demand for life insurance. This highlighted the important role of persuasion in the study of life insurance demand.

This study discovers that persuasion has strongest total effect among the five exogenous drivers, in which item 3 of the persuasion questionnaire, has been identified as the specific areas of persuasion significantly influencing the demand for life insurance. The values concerning the 'clarity of the information' communicated to the consumer are essential in determining the demand for life insurance. The 'clarity of information' corresponds with the central and peripheral route processing capabilities in the ELM model. This suggests that individual who process the persuasive messages via the central route are likely interested in the details of the products presented such as the sum assured, the rate of returns, the payment term, the exclusion and inclusion of the policy, the claims policy and the details of claim benefits. On the other hand, peripheral route processing individuals are more likely interested in the 'cosmetic' features of the products such as the sales agent representing the insurance company, the characteristic of the sales agent, the list of panel hospitals and provision of examples of claims event.

Based on the findings, training and development for agents should not be limited to product-oriented skill building alone, but extended to communication skills, specifically persuasion skills in the context of insurance products. Regular workshops and seminars might be an excellent platform for agents to explore their prospects' attitudes and behaviour. In addition, agents should be financially literate not limited to life insurance policies alone, but with the overall financial aspects in the economy. Financially less literate agents may not able to meet the expectation of central route processing capabilities of prospective insurance policy buyers. 
Results from this study contributes to the existing body of knowledge for policy makers such as Bank Negara Malaysia (Central Bank), Life Insurance Association of Malaysia, Malaysian Insurance Institute (MII), insurance companies and agents, and academic institutions that offers insurance programmes in implementing their strategies to increase life insurance penetration rate in the developing country.

The limitation of this study includes the examination of only six independent variables in relation to life insurance demand. Future studies could expand this study with more dimensions that affects the demand for life insurance, by looking at current issues of employee wellbeing and greater healthcare promotions at workplace due to pandemic (Gorgenyi et al., 2021). The framework presented in this study can be expanded to other regions, since the theoretical and empirical model would have relevance to other countries as well, particularly developing countries.

Additionally, the recent pandemic of Covid-19 has had major impacts on our lives, driving communities into the digital realm. The same phenomenon is impacting the life insurance industry. Insurance agencies are also moving online to offer insurance policies. Prospective buyers can compare and purchase insurance policies online, including life insurance. However, the efficacy of purchasing life insurance online especially when it comes to claims is less understood and requires further study. Future research could investigate three major fields of digital landscape in insurance, specifically on the variety of new digital distributions channels, new data for underwriting and digital services requirements for policy owners.

\section{REFERENCES}

Aliman, N. K., Ariffin, Z. Z., \& Hashim, S. M. (2018). Religiosity Commitment and Decision-Making Styles Among Generation Y Muslim Consumers in Malaysia Religiosity Commitment and Decision-Making Styles Among Generation Y Muslim Consumers in Malaysia. 8(1), 554-576. https://doi.org/10.6007/IJARBSS/v8-i1/3830

Arifin, J. (2015). International Review of Management and Business Research Demand of Family Takaful in Malaysia: Critical Determinant Factors Examined. International Review of Management and Business Research Papers, 3(2), 983992.

Arifin, J., Yazid, A. S., \& Sulong, Z. (2013). A Conceptual Model of Literature Review for Family Takaful (Islamic Life Insurance) Demand in Malaysia. International Business Research, 6(3), $210-216$. doi:https://doi.org/10.5539/ibr.v6n3p210

Arych, M., \& Darcy W. (2020). General trends and competitiveness of Australian life insurance industry. Journal of International Studies, 13(1), 212-233.

Attorney General's Chamber of Malaysia. (2006). Law of Malaysia Act 21 (Age of Majority, Act 1971). Retrieved September 10, 2020, from http://www.agc.gov.my/agcportal/uploads/files/Publications/LOM/EN/Act 21.pdf

Bernama.com. (2019). Life Insurance records moderate growth in 2018. Retrieved April 19, 2020, from Bernama.com website: http:/ /www.bernama.com/en/news.php?id=1701000

Bieck, C., Maas, P., \& Schlager, T. (2012). Insurers, intermediaries and interactions. From channels to networks. IBM Global Business Services.

Boubehrezh, S., \& Iraji, M. (2013). The Study of Persuasion language in Life Insurance Advertisements. International Research Journal of Applied and Basic Sciences, 6(2), 267-270.

Brychko, M., Bilan, Y., Lyeonov, S., \& Mentel, G. (2020). Trust crisis in the financial sector and macroeconomic stability: a structural equation modelling approach. Economic Research-Ekonomska Istraživanja, doi: 10.1080/1331677X.2020.1804970

Buric, M. N., Bacovic, M., Cerovic, J., \& Bozovic, M. L. (2017). Factors Influencing Life Insurance Market Development in Montenegro. Periodica Polytechnica Social and Management Sciences, 25(2), 141-149.

Byrne, B. M. (2012). Structural Equation Modeling with Mplus Multivariate Applications Series. Routledge: Taylor \& Francis Group. doi: https://doi.org/10.4324/9780203807644 
Chimedtseren, E., \& Safari, M. (2016). Service Quality Factors Affecting Purchase Intention of Life Insurance Products. Journal of Insurance and Financial Management, 01(01), 1-12.

Chua, Y. P. (2013). Mastering Research Statistic. McGraw-Hill Education (Malaysia) Sdn Bhd.

Cyr, D., Head, M., Lim, E., \& Stibe, A. (2018). Using the elaboration likelihood model to examine online persuasion through website design. Information and Management, 55(7), 807-821. doi: https://doi.org/10.1016/j.im.2018.03.009

Dash, G. (2018). Determinants of Life Insurance Demand: Evidences from India. Asia Pacific Journal of Advanced Business and Social Studies, 4(2), 86-99. doi: 10.25275/apjabssv4i2bus10

Descombes, J. (2021). Why hasn't Covid-19 led to an increase in life insurance protection? SwissRe. https://www.swissre.com/institute/research/topics-and-risk-dialogues/health-and-longevity/covid-19-lifeinsurance.html

Diebold, F. X., Doherty, N. A., \& Herring, R. J. (2015). The Known, the Unknown, and the Unknowable in Financial Risk Management. (June), 1-30. Princeton University Press. doi: https://doi.org/10.1515/9781400835287

Dragos, S. L. (2014). Life and non-life insurance demand: the different effects of influence factors in emerging countries from Europe and Asia. Economic Research-Ekonomska Istrą̌ivanja, 27(1), 169-180.

Dragos, S. L., Mare, C., Dragota, I-M., Dragos, C. M., \& Muresan, G. M. (2017). The nexus between the demand for life insurance and institutional factors in Europe: new evidence from a panel data approach. Economic ResearchEkonomska Istrą̌ivanja, 30(1), 1477-1496.

Friedman, M., \& Savaje, L. J. (1948). Political Economy. The Journal of Political Economy, LVI(4), 279-304.

Gadzhiyeva, N. M., \& Sager, K. L. (2017). Maximizing the persuasiveness of a salesperson: An exploratory study of the effects of nonverbal immediacy and language power on the extent of persuasion. Revista de Psicologia Del Trabajo y de Las Organizaciones, 33(2), 83-93. https://doi.org/10.1016/j.rpto.2017.03.001

Görgényi E.H., Nathan R.J, Farkas M.F. (2021). Workplace Health Promotion, Employee Wellbeing and Loyalty during Covid-19 Pandemic - Large Scale Empirical Evidence from Hungary. Economies, 9(2), 55; https://doi.org/10.3390/economies9020055

Hair, J. F., Hult, G. T. M., Ringle, C. M., \& Sarstedt, M. (2017). A Primer on Partial Least Squares Structural Equation Modeling (PLS-SEM) (2nd ed.). SAGE: Thousand Oaks, doi: https://doi.org/10.1007/s10995-012-1023-x

Hao, L., Arsiah, B., Awangku, H. B. P. B. (2017). Social support change as a moderator and organizational commitment as a mediator between pre-entry expectation and turnover intention: A study among life insurance agents in Tianjin, China. Polish Journal of Management Studies, 15(2), 58-68.

Henseler, J., Ringle, C. M., \& Sinkovics, R. R. (2009). The Use of Partial Least Squares Path Modeling in International Marketing. Advances in International Marketing, 20(4), 277-319. doi: https://doi.org/10.1016/01678116(92)90002-3

Hasyim, H. (2017). Consumers' Trust As the Mediating Factor for Insurance Buying Intention in Indonesia. Statistics, 3(2), 894.

Jacobs-Lawson, J., \& Hershey, D. (2005). Influence of future time perspective, financial knowledge, and financial risk tolerance on retirement saving behaviors. Financial Services Review, 14(August), 331-344.

Kjosevski, J. (2012). The Determinants of Life Insurance Demand in Central and Southeastern Europe. International Journal of Economics and Finance, 4(3), 237-247.

Krejcie, R. V., \& Morgon, D. W. (1970). Determining Sample Size for Research Activities. Educational and Psychological Measurement, 30(3), 607-610. doi: https://doi.org/10.1261/rna.2763111

Liebertberg, A. P., Carson, J. M., \& Dumm, R. E. (2012). A Dynamic Analysis of E Demand for Life Insurance. The Journal of Risk and Insurance, 79(3), 619-644. doi: https://doi.org/10.1111/j.1539-6975.2011.01454.x

Lien, N.-H. (2001). Elaboration Likelihood Model in consumer research: A review. Proceedings of the National Science Council, 11(4), 301-310.

Life Insurance Association of Malaysia. (2013). Addressing the Life Insurance Protection Gap in Malaysia. Retrieved April 19, 2019, from Life Insurance Association of Malaysia website: https://www.liam.org.my/index.php/newsmedia$\mathrm{room} /$ media-releasepress-statements/english/200-addressing-the-life-insurance-protection-gap-in-malaysia-

LIAM Life Insurance Association of Malaysia (2021). Annual Report. Retrieved April 20, 2021, from Life Insurance Association of Malaysia website: https://www.liam.org.my/flip/2020/mobile/index.html 
Loke, Y. J., \& Goh, Y. Y. (2013). Purchase Decision of Life Insurance Policies among Malaysians. International Journal of Social Science and Humanity, 2(5), 415-420. https:/ / doi.org/10.7763/IJSSH.2012.V2.137

Lorant, A., \& Fekete Farkas, M. (2015). Risk Management in the Agricultural Sector with Special Attention to Insurance. Polish Journal of Management Studies, 11(2), 71-82.

Lusardi, A. (2015). Financial literacy: Do people know the ABCs of finance? Public Understanding of Science, 24(3), 260271. https://doi.org/10.1177/0963662514564516

Mahdzan, N. S., \& Tabiani, S. (2013). The impact of financial literacy on individual saving: An exploratory study in the Malaysian context. Transformations in Business and Economics, 12(1), 41-55.

Mahdzan, N. S., \& Victorian, P. S. M. (2013). The determinants of life insurance demand: A focus on saving motives and financial literacy. Asian Social Science, 9(5), 274-284. doi: https://doi.org/10.5539/ass.v9n5p274

Malaysian Takaful Association. (2013). The Story of Gap, Charting Takaful Growth in Malaysia. Retrieved April 19, 2019 from http://www.actuarialpartners.com/wp-content/uploads/2015/02/The-Story-of-Gap-Charting-TakafulGrowth-in-Malaysia-Feb15.pdf

Malyovanyi, M., Nepochatenko, O., \& Nesterchuk, Y. (2018). Conceptual Approaches to Improving the Functioning of Nonstate Social Insurance Institutions in Ukraine. Economics and Sociology, 11(2), 289-304.

Mapharing, M., Otuteye, E., \& Radikoko, I. (2015). Determinants of Demand for Life Insurance: The Case of Canada. Journal of Comparative International Management, 18(2), 1-22.

Masci, P. (2011). The History of Insurance: Risk, Uncertainty and Entrepreneurship. Journal of the Washington Institute of China Studies, 5(3), 25-68.

McNeish, D. (2017). Thanks Coefficient Alpha, We'll Take it From Here. Psychological Methods, 23(3), 412-433. doi: https://doi.org/10.1037/met0000144

Md Masnun Al Mahi, A. S., Hassan, A. F. S., \& Sim, C. S. (2017). Religiosity and Demand for Takaful (Islamic Insurance): A Preliminary Investigation. International Journal of Applied Business and Economic Research, 15(24), 485499.

Mohamed, O. E. B., \& Syed O. A. (2013). Factors influencing the penetration rate of Malaysian takaful industry from takaful managers' perspective. International Journal of Excellence in Islamic Banking \& Finance, 5(March), 353-366.

Nathan, R.J., Victor, V., Gan, CL \& Kot, S. (2019). Electronic Commerce for Home-Based Businesses in Emerging and Developed Economy, Eurasian Business Review. 9(4), 463-483. https://doi.org/10.1007/s40821-019-00124$\mathrm{x}$

Nathan, R. J., Chiun, D. C., \& Suki, N. M. (2021). An Online Marketing Strategies Assessment for Companies in Airlines and Entertainment Industries in Malaysia. In Management Association, I. (Ed.), Research Anthology on Reliability and Safety in Aviation Systems, Spacecraft, and Air Transport, 1298-1313. IGI Global. http://doi:10.4018/978-1-7998-5357-2.ch053

Ng, Yiing., Khong, C.W. \& Nathan, R.J. (2018). Evaluating Affective User-Centered Design of Video Games Using Qualitative Methods. International Journal of Computer Games Technology, 2018, Article ID 3757083, 13 pages doi.org/10.1155/2018/3757083

Nor, N. B. M., \& Kamil, N. M. (2014). Factors Influencing the Choice of Takaful over Conventional Insurance: The Case of Malaysia. Journal of Islamic Finance, 3(2), 1-14. doi: https:/ doi.org/10.12816/0025101

Noriszura, I., Asnawi A., \& Anuar, A. (2015). Deductibles, Policy Limits and Reinsurance: A Case Study in Malaysia. Casualty Actuarial Society E-Forum, Winter 2011, Volume 2

OECD (2021). OECD Insurance Statistics. Retrieved May 20, 2021: https://www.oecd.org/daf/fin/insurance/oecdinsurancestatistics.htm

Onifade N. (2011). Why Insurance is Sold and Not Bought. Retrieved April 20, 2020, from https://www.megainsights.com/why-life-insurance-is-sold-and-not-bought/

Panigrahi, S. K., Azizan, N. A., \& Khan, M. W. A. (2018). Investigating the empirical relationship between service quality, trust, satisfaction, and intention of customers purchasing life insurance products. Indian Journal of Marketing, 48(1), 28-46. https://doi.org/10.17010/ijom/2018/v48/i1/120734

Petty, R.E, \& Cacioppo, J. (1986). The elaboration likelihood model of persuasion. Advances in Experimental Social Psychology, 19, 123-205. https://doi.org/10.1558/ijsll.v14i2.309 
Petty, Richard E., \& Cacioppo, J. T. (1984). The Effects of Involvement on Responses to Argument Quantity and Quality: Central and Peripheral Routes to Persuasion. Journal of Personality and Social Psychology, 46(1), 69-81.

Ramayah, T., Cheah, J., Chuah, F., Ting, H., \& Memon, M. A. (2018). Partial Least Squares Structural Equation Modeling (PLS-SEM) using SmartPLS 3.0 (2nd Edition). Kuala Lumpur: Pearson.

Redzuan, H. (2014). Analysis of The Demand for Life Insurance and Family Takaful Hendon. Redzuan University Kebangsan Malaysia. Proceedings of the Australian Academy of Business and Social Sciences Conference 2014 (in partnership with The Journal of Developing Areas), 1-16.

Redzuan, H., Yakob, R., \& Isa, Z. (2016). Underinsurance in Malaysia: The application of the Monte Carlo simulation. Journal Pengurusan, 47, 131-141. doi: https://doi.org/10.17576/pengurusan-2016-47-11

Remli, N., Muda, M., \& Rosman, R. (2017). Family takaful demand in Malaysia: proposed theoretical framework and hypotheses developments. International Journal of Business, Economics and Law, 12(1), 2013-2017.

Salleh, F., \& Kamaruddin, A. R. (2011). The Effects of personality factors on Sales performance of Takaful (Islamic Insurance) Agents in Malaysia. International Journal of Business and Social Science, 2(5), 259-265.

Schlag, C-H. (2003). Determinants of demand for life insurance products - Theoretical concepts and empirical evidence. Swiss Re, Economic Research \& Consulting working papaer

Shafii, Z., Abiddin, N. Z., \& Ahmad, A. R. (2009). Ethnic Heterogeneity in the Malaysian Economy: A Special Reference to the Ethnic Group Participation in Financial Planning Activities. The Journal of International Social Research, 2(8), 394-401.

Sliwinski, A., Michalski, T., \& Roszkiewicz, M. (2013). Demand for Life Insurance-An Empirical Analysis in the Case of Poland. The Geneva Papers, 38, 62-87. doi: 10.1057/gpp.2012.21

Swiss Re Institute. (2020). World insurance in 2017: solid, but mature life markets weigh on growth. Retrieved April 19, 2019, from Swiss Re Institute website: https://www.swissre.com/institute/research/sigma-research/sigma-201803.html

Swiss Re Institute. (2021a). One year on: how COVID-19 has impacted consumer views on insurance in Asia Pacific.

Swiss Re Institute. (2021b). World insurance: the recovery gains pace.

Tanti, D. S., Nathan, R. J., Sulistyo, P. B., Soekmawati, Hanim, F. and Sarjuni, V. (2021). Empowering cross-border women entrepreneurs via mobile ICT: Framework for Malaysian and Indonesian women-led MSMEs. Journal of Nusantara Studies, 6(2), 340-357. http:/ /dx.doi.org/10.24200/jonus.vol6iss2pp340-357

Toth, R., Zeman, Z., Túróczi, I., Kása, R., Popp, J., \& Oláh, J. (2021). The system of relationships between sustainable corporate governance and corporate financial literacy. Polish Journal of Management Studies, 23(1), 418-435.

Victor, V., Nathan, R.J., Grabara, J. \& Farkas M.F. (2018). Price Tracking Behaviour in Electronic Commerce and The Moderating Role of Fair Price Perception. Polish Journal of Management Studies, 18(2): 375-387. doi: 10.17512/pjms.2018.18.2.30

Worthington, E. L. , Jr., Wade, N. G., Hight, T. L., Ripley, J. S., McCullough, M. E., Berry, J. W., Schmitt, M. M., Berry, J. T., Bursley, K. H., \& O’Connor, L. (2003). The Religious Commitment Inventory--10: Development, refinement, and validation of a brief scale for research and counseling. Journal of Counseling Psychology, 50(1), 84 96. https://doi.org/10.1037/0022-0167.50.1.84

Yazid, A. S., Arifin, J., Hussin, M. R., \& Wan Daud, W. N. (2012). Determinants of Family Takaful (Islamic Life Insurance) Demand: A Conceptual Framework for a Malaysian Study. International Journal of Business and Management, 7(6), 115-127. doi: https://doi.org/10.5539/ijbm.v7n6p115

Yu, T. W., \& Tseng, L. M. (2016). The role of salespeople in developing life insurance customer loyalty. International Journal of Retail and Distribution Management, 44(1), 22-37. https://doi.org/10.1108/IJRDM-06-2014-0074

Zakaria, Z., Azmi, N. M., Hassan, N. F. H. N., Salleh, W. A., Tajuddin, M. T. H. M., Sallem, N. R. M., \& Noor, J. M. M. (2016). The Intention to Purchase Life Insurance: A Case Study of Staff in Public Universities. Procedia Economics and Finance, 37(16), 358-365. https://doi.org/10.1016/S2212-5671(16)30137-X 